\section{If you go to San Francisco . . .}

\section{San Francisco}

SEEKING to sustain the position of the University of California San Francisco (UCSF) Medical School as a premiere biomedical research institution, a group of faculty members has put together a new programme that they hope will "both exploit and advance the revolution in biological research." With good prospects for funding and the promise of precious laboratory space from the medical school administration, the new Program in Biological Sciences (PIBS) may well supplant traditional departments in guiding graduate education and research.

As initially implemented, the new regime will involve a confederation of four graduate programmes; biochemistry, cell biology, genetics and neuroscience. While each member department will retain its individual identity, PIBS will admit graduate students, advise on new appointments, generate funds and foster cooperation among different disciplines. Guiding PIBS will be a board of faculty members, two from each of the member programmes, plus J. Michael Bishop who was acting as board chairman until he went on sabbatical at the beginning of this month.

To work, PIBS must effectively coordinate interdisciplinary research. But that should not be a problem, says PIBS board member James Hudspeth, since cooperation has always been a strong suit of the medical school faculty. For nearly 50 years, following the great earthquake in 1906, San Francisco's basic research faculty was exiled to the University of Califora relatively young and enthusiastic faculty plines in their work. nia Berkeley campus across the bay. It was

that returned to San Francisco in the 1960 s and 1970 s, bringing UCSF its current level of success. One measure of that success, boasts Dean Rudi Schmid, is that UCSF now receives about $\$ 80$ million in support from the National Institutes of Health, more than any other single institution.

For Bishop, the wide spectrum of faculty interests is what will make PIBS work. "Nothing succeeds like diversity", he says. $\mathrm{He}$ argues that traditional medical school departments are anachronisms, since modern biologists draw on several disci-

While membership in the new programme is at present limited to just four departments, expansion is inevitable. One goal of the new programme, says Hudspeth, is to prevent any one department from getting richer and "building a wall around itself". Biochemistry has been the most

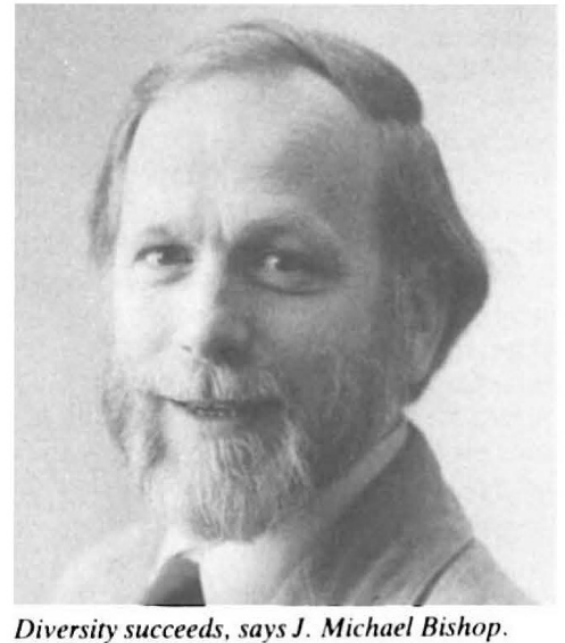

\section{Mutation screening an increasing factor}

Washington

Congress's Office of Technology Assessment (OTA) has provided a timely warning that new techniques for measuring human mutation rates will raise novel policy questions as their use becomes more widespread. The research office concludes* that within the next 5 or 10 years several new technologies for studying prevalence of mutations could be ready for large-scale epidemiological screening of populations at risk, such as those exposed to mutagenic chemicals or anticancer drugs.

The new techniques, such as analysis of restriction-fragment-length polymorphisms, electrophoresis of protein variants and DNA sequencing, have the potential not only to screen individuals for recessive genetic diseases, but also to assess populations for exposure to mutagenic influences such as some chemicals or radiation. Congress has already passed environmental successful department financially at the medical school, and there are those that worry that PIBS will merely become a vehicle for biochemistry's greater glory. But Bishop disagrees, arguing that by becoming equal partners with other departments, biochemistry has diluted its potential influence.

While officials at UCSF would like to claim that careful planning and administrative acumen is solely responsible for the cooperative spirit and academic success that the university enjoys, they cannot. Says Dean Schmid with a smile, the key factor was luck.

Joseph Palca

Oceans and atmosphere \section{Advisory group sinks}

\section{Washington}

IT looks like the end of the road for the National Advisory Committee on Oceans and Atmosphere. The 18-member committee, formed in 1975 to give the private sector an advisory role in ocean and atmosphere policy, is likely to disband on 1 October, and there seem to be few who will mourn its passing.

The committee, chaired by John Flipse of Texas A\&M University, was originally conceived as a means of giving the private sector a voice in policy advice; its members include representatives of academia and industry. But on Capitol Hill there is a growing feeling that the committee has become politicized and that it lacks the "expert" status it once had. And as it is staffed by employees of the National Oceanic and Atmospheric Administration, it lacks sufficient independence to give good advice.

The committee has recently concentrated on providing recommendations on the US Exclusive Economic Zone announced by President Reagan in 1983 . What will probably be its last opus is an assessment of the National Oceanic and Atmospheric Administration. But the administration feels the committee is giving it advice it does not need, and has been trying to abolish it for several years.

Congress has so far always stepped in at the last moment with a reprieve, but this year even Congress's patience with the committee seems to have been exhausted. A new bill has been introduced to establish a national marine policy commission, a blue-ribbon expert panel whose members would, unlike the committee, be nominated from a list provided by Congress. Among the issues the new commission would tackle are international marine policy, conservation of marine resources and establishment of proper roles for federal and state governments and the private sector in marine policy.

Tim Beardsley 